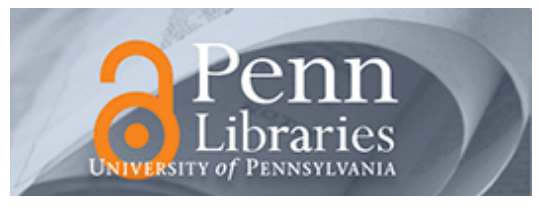

Studies in Visual Communication

Volume 6

Issue 2 Summer 1980

Article 2

1980

\title{
Introduction: A Reevaluation of Robert J. Flaherty, Photographer and Filmmaker
}

Jay Ruby

\section{Recommended Citation}

Ruby, J. (1980). Introduction: A Reevaluation of Robert J. Flaherty, Photographer and Filmmaker. 6 (2), 2-4. Retrieved from https://repository.upenn.edu/svc/vol6/iss2/2

This paper is posted at ScholarlyCommons. https://repository.upenn.edu/svc/vol6/iss2/2

For more information, please contact repository@pobox.upenn.edu. 
Introduction: A Reevaluation of Robert J. Flaherty, Photographer and Filmmaker 


\title{
Introduction: A Reevaluation of Robert J. Flaherty, Photographer and Filmmaker ${ }^{1}$
}

\author{
Jay Ruby
}

It is fashionable nowadays to be publicly self-conscious about what we know. Styles of inquiry are acknowledged to change through time. What we deem important and how we go about discovering it have themselves become the subject of inquiry. This issue of Studies exemplifies the trend. It contains an examination of Robert J. Flaherty's early career as photographer and filmmaker. The articles and photographs are the result of recent "excavations" in archives that contain the "artifacts" of his life. Since nothing was really lost, nothing new was discovered. What is new and what gives significance to the primary materials and the accompanying interpretive articles is the way in which we now regard them. Until now no one has apparently been very interested in Flaherty's Arctic photographs. Fortunately, Jo-Anne Birnie Danzker is, and through her efforts to organize an exhibition at The Vancouver Art Gallery and to edit a catalog (Danzker 1980), the impetus for this renewed interest in Flaherty's early career was created.

Until recently the dominant paradigm in visual research has been to examine the film or photograph as object or text, out of the context of its production and consumption. It was assumed that all important information was contained within the work itself, and only those people interested in gathering psychological tidbits about the author or in constructing a hero would bother to look at the maker's life.

As scholars became interested in examining the sociocultural processes of these cultural artifacts and saw the need for exploring the relationship between the producer, the process of production, the product itself, and its consumption, other data became relevant. The astonishing Arctic photographs of Robert Flaherty that appear here, Jo-Anne Birnie Danzker's essay, the promotional booklet for Nanook of the North, and Paul Rotha's study of Flaherty all combine to provide us with a new perspective.

Our interests have shifted from the "text" to the "context" as being of primary importance. We are beginning to realize it is important to understand not only the film or the photograph but the maker, the conditions of production, and the conditions of consumption if we wish to comprehend how meaning is created. Through Danzker's and Rotha's scholarship we are able to see the history and development of Flaherty's life in a new light. His

Jay Ruby is Associate Professor of Anthropology at Temple University and Co-Editor of Studies in Visual Communication. struggles to discover a creative and economic identity are made clear-from explorer-geologist to explorerphotographer-lecturer to independent filmmaker. We also have some glimpses into the social facts of his life with the people he photographed and filmed. Since many of us believe that a photograph or a film is the record of an interaction between the filmer and the filmed, this information is especially valuable.

It is a privilege to publish Paul Rotha's study, without question the best piece of work on Nanook. It comes from his biographical study of Flaherty, completed in 1959 but at that time deemed too sophisticated to be published. Arthur Calder-Marshall obtained the rights to use it as research notes for his biography on Flaherty, The Innocent Eye (1963). So while Rotha's work was finished more than 20 years ago, it is appearing in print for the first time here.

Robert Flaherty is a curious figure in film history. $\mathrm{He}$ is probably more revered than any other American filmmaker. The construction and perpetuation of the "Flaherty myth" have been the subject of numerous articles (see Barsam 1973; Corlis 1973; Griffith 1953; Van Dongen 1965). Rotha's article places the personage of Flaherty within a context whereby neither hero worship nor iconoclasm is necessary or even very interesting.

Flaherty has for some time enjoyed a reputation as the prototypical independent film artist. The importance of the word "independent" cannot be overly stressed when one compares film to other media. The technology and cost of producing most films cause the filmmaker to have to effect some sort of working relationship with commerce in a way that marks and separates him from other artists (except video makers, who are even more tied to the commercial broadcast industry). Until the recent years of foundation and government support, the filmmaker had only three places to go: the commercial film industry, wealthy patrons (who seldom saw film as an "art" worth supporting), and companies that might be cajoled into thinking that backing a film could be both profitable and good public relations. When Flaherty convinced Revillon Frères to produce Nanook, he started the tradition of companies supporting the independent film artist.

As a consequence of the confluence of circumstances and Flaherty's ability to be an excellent advertisement for himself, he is regarded as a paragon of artistic virtue and integrity - admired for his unswerving commitment to his own artistic values - someone unseducible by the money sirens of Hollywood. Flaherty was the object of awe and reverence among Hollywood and New York commercial, intellectual, and artistic circles. Producer-director-actor John Houseman (whose own career spans Citizen Kane to The Paper Chase) once wrote about Flaherty: "It is the measure of his greatness that after a quarter of a century Flaherty's myth is today more valid, more universal, and 
more significant than ever before. And it is no wonder. For it is rooted in love. And what it tells is a story of the innate decency and fortitude and invincibility of the human spirit" (cited in Taylor 1949:43).

It could be argued that if Flaherty did not exist, Hollywood and New York would have had to invent him. They needed a figure to point to as having sufficient artistic integrity to resist the financial temptations of the commercial film establishment. In his New Yorker Profile of Flaherty, written in 1949, Robert Lewis Taylor introduced Flaherty to that magazine's sophisticated readership.

His life to date has been a brilliant demonstration of the axiom that art doesn't pay. . . . From time to time he has been mixed up briefly in the production of a few other films, withdrawing in most cases after some truly memorable wrangles over commercialism vs. artistic integrity. . . . Though unopposed to earning an honest dollar, Flaherty was, and is today, repelled by the gross taint of commercialism; ignoring the Hollywood moneypots, he searched for a private patron . . . he was wholly undismayed by the commercial failure of three movies he had made and the artistic collapse of a fourth, which he had worked on briefly. . . . Flaherty's case, with its slights, rebuffs, hardships, disasters, and general lack of rewards, illustrates the depressing battle that faces an artist relentlessly dedicated to raising the standard of a new cultural medium (emphasis added).

Flaherty was accepted among East Coast artistic and intellectual circles, and in Hollywood as America's native son in a world of art film dominated by Italian NeoRealism and the newly discovered Russians such as Eisenstein. It must have been easier for these people, who were convinced that all culture and art came across the Atlantic, to accept the vulgar American Flaherty as their own home-grown genius when they discovered that "Serge Eisenstein, the Russian producer, said, 'We Russians learned more from 'Nanook of the North' than from any other foreign film. We wore it out studying it. That was, in a way, our beginning'" (cited in Taylor 1949).

There is, of course, some substance to the image. In addition to obtaining Revillon Frères' sponsorship, Flaherty secured financial backing from Paramount Pictures (Moana), Standard Oil (Louisiana Story), and the U.S. government (The Land). In virtually every case the relationship was mutually unsatisfying. He went over budget almost every time. He even walked out of several productions because of disputes with the management. Now, depending upon one's point of view, these were either the actions of an artist who could not and should not have been burdened by the limitations of a commericial industry or the unjustifiable actions of an unreasonable and undisciplined prima donna.
The tensions and conflicts between the commercial/ theatrical and the artistic, educational, and socially concerned interests were certainly endemic to the cinema from the moment of its inception. In addition, there are the problems faced by the filmmaker who wishes to make a living from his films but who needs or wishes to remain outside the commercial industry. All these tensions and problems are to be found within the career of Robert Flaherty. His solution is instructive.

In order to understand Flaherty's choices in these matters, one must first contextualize them in the world of film during the formative period of Flaherty's career, 1914 to 1920. There were virtually no nontheatrical film outlets of any consequence. A handful of people made a living making travelogues. There was a smattering of screenings in schools, churches, union halls, and a few nascent film societies. However, 99 percent of the funds and activities were to be found in the commercial theatrical world. This situation remained virtually unchanged until the 1950s, when film groups such as Amos Vogel's Cinema 16 and the Museum of Modern Art in New York began to create alternative outlets for films.

It is quite clear that Flaherty was torn between his need to make a living, the attraction of big money and its promise of future projects, his desire to have his work seen, and the lure of other, less commercial interests. An examination of Frances Flaherty's diary during the period when she was attempting to sell the 1914 film in New York to a distributor demonstrates the degree of ambivalence they both felt about the work-from delusions of grandeur, assuming that their footage was saleable to Paramount for $\$ 100,000$ - to wanting to devote their lives to educational films.

When Flaherty's plans for an illustrated travel lecture film went up in smoke, he went back to the North to film Nanook. He returned with a feature-length theatrical film, with an investor looking to recoup the investment. Given his decision, he had only one possible outlet-the large theatrical distribution companies. He landed Pathé Pictures, which logically did what it knew how to do--promote Nanook as a movie.

Today the "Campaign Book for Exhibitors," published and sent by Pathé to local exhibitors to promote Nanook, looks like a tacky ad campaign pandering to the lowest common denominator of public taste. It should serve as a reminder of the socioeconomic realities facing Flaherty. It would be easy to use this booklet as evidence that Flaherty "sold out." Flaherty either actively participated in or was at least a passive supporter of promotional campaigns for several of his other films that were not exactly "uplifting." When Moana failed to "test" well in some preview screenings, Paramount released it as "The Love Story of a South Sea Siren." When Man of Aran was premiered in England and the United States, Flaherty paraded his "players" on stage as the first documentary pop stars. And, finally, there is the unfortunate story of how Sabu the Elephant Boy took the road to fame and ruin, sparked by Flaherty's discovering him in India. 
Before one makes too facile a judgment about Flaherty's decisions to acquiesce to the commercial realities of theatrical cinema, one must realize the complexities of the situation. Flaherty had two viable options: theatrical release or the travelogue circuit. Both outlets promoted their wares in similar fashion, the only real difference being the size of their budgets. It is quite clear from her diary that Frances scoured New York for backers. Short of refusing to release the film, Flaherty had little choice - either accept the commercial realities of the time or cease being a filmmaker.

It is clear that he did not care for these conditions. When they continued with Moana, his second film, he tried without success to create an alternative.

Paramount's head distribution executive told Flaherty that if he had had a series of good, modest-budget pictures, he could have built up the sort of specialized distribution Flaherty wanted. But economically it wasn't worthwhile to do it for a single picture. Appreciating that his problem concerned not merely Paramount, but the cinema industry as a whole, not merely himself, but other directors of "off-beat" films, Flaherty approached the Rockefeller Foundation with the suggestion that a special organization should be built up to draw the attention of the "latent audience" to unusual films from any part of the world. A meeting of their board was arranged to discuss the project and a representative agreed that the proposal was interesting, but its implementation ought to come within the province of the Hays Organization rather than of a special foundation. [Calder-Marshall 1963:120]

Flaherty started the battle that is still being fought by independent filmmakers. He wanted his work to be seen by large audiences, and he wanted to earn a living through his films. His decision was to continue to produce films by making the concessions that were necessary at the time, a decision that should be familiar to all filmmakers.

Lest anyone think that this introduction suggests that previously published materials on Flaherty were incorrect or even inadequate and that now we have the definitive word on the man and his films, I wish to disabuse them of that interpretation. The contents of this issue are a reflection of what happens when one asks questions that have not been asked before. What occurs is, of course, the discovery that readily available answers are seldom sufficient. In the future, when other questions are asked about Flaherty and his works, the answers offered here will in turn appear to be less than complete.

\section{Note}

1 An expanded version of this paper appeared as "The Aggie Must Come First: The Demystification of Robert J. Flaherty" in Robert J. Flaherty: Photographer and Filmmaker edited by Jo-Anne Birnie Danzker (1980).

\section{References}

- Barsam, Richard

1973 The Humanistic Vision of Robert Flaherty. In Nonfiction Film: A Critical History. Richard Barsam (ed.). New York: Dutton.

- Calder-Marshall, Arthur

1963 The Innocent Eye: The Life of Robert J. Flaherty. London: W. H. Allen.

- Corliss, Richard

1973 Robert Flaherty: The Man in the Iron Myth. Film Comment 9:38-42.

- Danzker, Jo-Anne Birnie (ed.)

1980 Robert Flaherty-Photographer and Filmmaker. Vancouver: The Vancouver Art Gallery.

- Griffith, Richard

1953 The World of Robert Flaherty. New York: Duell, Sloan and Pearce.

- Taylor, Robert Lewis

1949 A Profile of Robert Flaherty. The New Yorker, June .11, 18, and 25.

- Van Dongen, Helen

1965 Robert J. Flaherty: 1884-1951. Film Quarterly 18(4):2-14. 